\title{
ANALISIS FAKTOR-FAKTOR YANG MEMPENGARUHI AUDIT DELAY (STUDI EMPIRIS PADA PERUSAHAAN YANG TERDAFTAR SEBAGAI ANGGOTA LQ45 DI BEI PERIODE 2010-2015)
}

\author{
Lista Wardan ${ }^{1}$, Mushawir $^{2}$ \\ ${ }^{12}$ Program Studi Akuntansi Fakultas Ekonomi Universitas Mercubuana Yogyakarta \\ ${ }^{1}$ Email: listawardani@gmail.com
}

\begin{abstract}
Abstrak
Skripsi ini membahas tentang "Analisis Faktor-Faktor Yang Mempengaruhi Audit Delay (Studi Empiris pada Perusahaan yang Terdaftar Sebagai Anggota LQ45 di BEI Periode 2010-2015)”. Tujuan penulisan skripsi ini adalah untuk menguji apakah faktor ukuran KAP, ukuran perusahaan, tingkat leverage, serta profitabilitas mampu mempengaruhi terjadinya audit delay pada laporan keuangan perusahaan. Penulisan skripsi ini merujuk pada adanya inkonsistensi hasil dari beberapa penelitian dengan judul serupa. Penulisan skripsi ini mengunakan metodologi statistik deskriptif. Data yang digunakan adalah data sekunder berupa laporan keuangan auditan perusahaan yang tercatat dalam indek LQ45 pada Bursa Efek Indonesia Periode 2010 - 2015. Hasil penelitian melalui bantuan olah data statistic menggunakan SPSS versi 23 menunjukkan bahwa ukuran KAP, ukuran perusahaan dan tingkat leverage tidak mempengaruhi terjadinya audit delay. Sebaliknya, profitabilitas perusahaan mempengaruhi terjadinya audit delay. Berdasarkan uji simultan, keempat variabel bebas secara bersama-sama mempengaruhi variabel terikat.
\end{abstract}

Kata kunci : ukuran KAP, ukuran perusahaan, tingkat leverage, profitabilitas, audit delay

\section{ANALYSIS OF FACTORS AFFECTING AUDIT DELAY (EMPIRICAL STUDY ON COMPANIES REGISTERED AS LQ45 MEMBERS IN BEI PERIOD 2010-2015)}

\author{
Lista Wardan ${ }^{1}$, Mushawir ${ }^{2}$ \\ ${ }^{12}$ Program Studi Akuntansi Fakultas Ekonomi Universitas Mercubuana Yogyakarta \\ ${ }^{1}$ Email: listawardani@gmail.com
}

\begin{abstract}
This thesis discusses "Analysis of Factors Affecting Audit Delay (Empirical Study on Companies Registered as LQ45 Members in BEI Period 2010-2015)". The purpose of writing this thesis is to test whether the KAP size factor, firm size, leverage level, and profitability can affect the occurrence of audit delay on the company's financial statements. Writing this thesis refers to the inconsistency of results from several studies with similar titles. Writing this thesis using descriptive statistical methodology. The data used is secondary data in the form of audited financial statements of companies listed in the index LQ45 on Indonesia Stock Exchange Period 2010-2015. The results of research through statistical data processing using SPSS version 23 shows that KAP size, firm size and leverage level does not affect the occurrence of audit delay. In contrast, firm profitability affects the occurrence of audit delay. Based on the simultaneous test, the four independent variables together influence the dependent variable.
\end{abstract}

Keyword : KAP size, firm size, leverage level, profitability, audit delay 


\section{PENDAHULUAN}

Laporan keuangan merupakan media informasi yang memiliki peranan penting dalam mengungkapkan mengenai kondisi keuangan suatu perusahaan tertentu. Penyusunan laporan keuangan bertujuan untuk memenuhi kebutuhan informasi para pemangku kepentingan baik pihak internal maupun eksternal perusahaan. Berkembanganya kebutuhan informasi dari pihak yang memiliki kepentingan menimbulkan kebutuhan akan laporan keuangan yang tepat waktu dan akurat. Tepat waktu dan akurat artinya ketersediaan informasi yang dibutuhkan para pengambil keputusan sebelum informasi di dalam laporan keuangan tersebut kehilangan daya dalam mempengaruhi pengambilan keputusan. Oleh karena itu laporan keuangan harus diterbitkan sesegera mungkin setelah periode pencatatan akuntansi berakhir. Berdasarakan peraturan Nomor. KEP431/BL/2012 yang dikeluarkan oleh Ketua Badan Pengawas Pasar Modal dan Lembaga Keuangan. Peraturan tersebut mewajibkan penyampaian laporan tahunan oleh emiten atau perusahaan publik yang pernyataan pendaftarannya telah menjadi efektif wajib menyampaikan laporan tahunan kepada Bapepam dan LK paling lama 4 (empat) bulan setelah tahun buku berakhir. Keterlambatan dalam menyampaikan laporan keuangan inilah yang disebut audit delay. Audit delay adalah lamanya waktu penyelesaian audit diukur dari berakhirnya tahun fiskal sampai dengan tanggal ditandatanganinya laporan audit (tanggal opini).

Audit delay atau dalam beberapa penelitan sebagai audit reporting lagi didefenisikan sebagai selisih waktu antara berakhirnya tahun fiskal sampai dengan tanggal diterbitkannya laporan audit. Jangka waktu audit delay terhitung dari tanggal berakhirnya periode pencatatan laporan keuangan suatu perusahaan hingga tanggal diterbitkannya laporan auditor. Semakin panjang jangka waktu audit delay maka semakin lama juga laporan keuangan bisa dipublikasikan, yang juga akan semakin memberi sinyal buruk terhadap para investor atas prediksian abnormal return yang negatif (Chambers dan Penman, 1984). Turel (2010) dalam Wahyu (2016) menyebutkan determinan yang mempengaruhi panjangnya durasi audit delay dapat berasal dari faktor dari auditor independen perusahaan (audit related factors) maupun faktor internal perusahaan dalam menyusun laporan keuangan (company specific factors) itu sendiri.

Faktor yang mempengaruhi panjangnya audit delay dari segi eksternal perusahaan salah satunya adalah dari segi auditor yang dapat dilihat dari ukuran 
KAP yang melakukan audit pada laporan keuangan suatu perusahaan. Menurut teori atribusi, faktor pengalaman, kemampuan, keterampilan serta motivasi menjadi keunggulan KAP yang tergabung dalam big four sehingga KAP big four dapat menyelesaikan pekerjaan audit dengan lebih efektif dan efisien. Teori pragmatis menelaah bagaimana kaitan antara simbol yang telah dimaknai dan kaitannya dengan perilaku penerima. Profitabilitas atau tingkat keuntungan perusahaan merupakan alat yang menjadi tolak ukur bagi kinerja manajemen perusahaan sebagai faktor internal perusahaan yang mampu mempengaruhi terjadinya audit delay. Dalam terori struktur modal, dikemukakan bahwa bauran pendanaan (financing mix) dapat mempengaruhi nilai perusahaan. Hal ini memotivasi manajemen perusahaan untuk mencari suatu struktur modal yang optimal bagi perusahaannya. Suatu penentuan tingkat leverage keuangan yang optimal atau komposisi pendanaan optimal dengan meminimalkan biaya modal perusahaan adalah setara dengan memaksimalkan nilai pasar perusahaan (Sawir, 2004:43). Rasio yang tinggi menunjukkan bahwa perusahaan memiliki hutang/financial leverage yang tinggi. Penggunaan hutang yang tinggi inilah yang akan menyebabkan peningkatan profitabilitas sekaligus resiko pengembalian hutang yang dihadapi perusahaan. Oleh karena itu, untuk memperoleh keyakinan akan laporan keuangan perusahaan maka auditor akan lebih berhati-hati sehingga jangka rentang waktu audit akan lebih panjang.

Pengamatan diarahkan lebih spesifik dengan menggunakan sampel data dari perusahaan- perusahaan yang terdaftar dalam Bursa Efek Indonesia dan tercatat pada indeks LQ45. Indeks LQ45 terdiri dari 45 emiten terdaftar di Bursa Efek Indonesia dengan likuiditas (LiQuid) tinggi dan sahamnya paling aktif diperjual belikan. Penelitian ini adalah hasil replikasi dari beberapa penelitian sebelumnya yang telah meneliti faktorfaktor yang mempengaruhi audit delay. Beberapa penelitian tersebut diantaranya Wahyu (2016), Febrina (2016), Tria (2016), dan Eko (2016). Dari hasil beberapa penelitian yang pernah dilakukan sebelumnya terdapat inkonsistensi hasil penelitian. Oleh karena itu, peneliti mencoba untuk menguji dan menganalisis kembali dengan menggunakan periode data penelitian (time series) yang lebih lama dengan menggunakan data dari perusahan yang tercatat dalam indeks LQ45 selama periode 2010-2015. Hal ini bertujuan agar penelitian ini selain memiliki faktor pembeda dari penelitian sebelumnya serta mampu memperoleh hasil dan kesimpulan 
yang lebih akurat. Berdasarkan latar belakang tersebut maka peneliti tertarik untuk melakukan penelitian dengan judul Analisis Faktor-Faktor Yang Mempengaruhi Audit Delay (Studi Empiris Pada Perusahaan Yang Terdaftar Sebagai Anggota Lq45 Di Bei Periode 2010-2015).

\section{METODE}

\section{Jenis Penelitian}

Penelitian ini menggunakan pendekatan kuantitatif yang bersifat deskriptif yang menjabarkan data yang diperoleh dengan menggunakan analisis regresi berganda untuk menggambarkan fenomena atau karakteristik dari data, yaitu dengan memberikan gambaran tentang pengaruh faktor-faktor yang mempengaruhi audit delay.

\section{Lokasi Penelitian}

Penelitian ini dilaksanakan pada Bursa Efek Indonesia dengan menggunakan laporan keuangan auditan dan mengunduh dalam situs resmi Bursa Efek Indonesia www.idx.co.id. Objek dalam penelitian ini adalah perusahaanperusahaan LQ45 yang terdaftar di BEI pada tahun 2010-2015. Penelitian ini akan dilakukan pada bulan Desember 2016 sampai dengan Februari 2017.

\section{Jenis dan Sumber Data}

Dalam penelitian ini data yang digunakan adalah data sekunder berupa laporan keuangan auditan perusahaan yang tercatat dalam indeks LQ45 pada Bursa Efek Indonesia periode 2010 2015. Data dalam penelitian ini diperoleh dari website resmi Bursa Efek Indonesia www.idx.co.id .

\section{Teknik Pengumpulan Data}

Teknik pengumpulan data ini menggunakan teknik pengumpulan data arsip (archival). Data yang digunakan dalam penelitian ini adalah data sekunder yang diperoleh/bersumber dari website resmi Bursa Efek Indonesia www.idx.co.id Metode Analisis Data

1. Statistik Deskriptif

Statistik deskriptif merupakan proses transformasi data penelitian dalam bentuk tabulasi sehingga mudah dipahami dan diinterpretasikan. Tabulasi menyajikan ringkasan, pengaturan, atau penyusunan data dalam bentuk tabel numerik dan grafik.

2. Uji Asumsi Dasar Klasik Regresi. Asumsi klasik yang diuji yaitu: normalitas, multikolinearitas, heteroskedastisitas, dan autokorelasi.

a. Uji Normalitas

Uji normalitas bertujuan untuk menguji apakah dalam model regresi, variabel terikat dan variabel bebas 
keduanya mempunyai

distribusi normal.

b. Uji Multikolinearitas

Multikorelasional berarti ada hubungan linier yang sempurna atau pasti diantara beberapa atau semua variabel yang independen dari model yang ada.

c. Uji Heteroskedastisitas

Uji heteroskedastisitas adalah suatu keadaan di mana varians dan kesalahan pengganggu tidak konstan untuk semua variabel bebas.

d. Uji Autokorelasi

Uji autokorelasi bertujuan menguji apakah dalam model regresi linear ada korelasi antara kesalahan pengganggu pada periode $t$ dengan kesalahan penganggum $t-1$ (sebelumnya). Jika terjadi korelasi, maka dinamakan ada problem autokorelasi. Autokorelasi muncul karena ada observasi yang berurutan sepanjang waktu berkaitan satu sama lainya.

3. Analisis Regresi Berganda

Penelitian ini bertujuan untuk melihat pengaruh antara variable independen dan variabel dependen dengan skala pengukuran atau rasio dalam suatu persamaan linear, dalam peneltian ini digunakan analisis regresi berganda yang diolah dengan bantuan perangkat lunak SPSS versi 23.

Persamaan regresi yang digunakan dalam penelitian ini adalah sebagai berikut.

$\mathrm{Y}=\mathrm{a}+\mathrm{b} 1 \mathrm{X} 1+\mathrm{b} 2 \mathrm{X} 2+\mathrm{b} 3 \mathrm{X} 3+\mathrm{b} 4 \mathrm{X} 4$

$+\mathrm{e}$

Keterangan :

$\mathrm{Y}=$ Audit Delay

$\mathrm{a}=$ Bilangan konstanta $\mathrm{b} 1$ -

b4 $=$ Koefisien regresi

$\mathrm{X} 1=$ Ukuran KAP

X2 = Ukuran Perusahaan

X3 = Tingkat Leverage

$\mathrm{X} 4=$ Profitabilitas Perusahaan

e $\quad=$ koefisien eror

a. Uji simultan (Uji F)

Signifikansi model regresi secara simultan diuji dengan melihat nilai signifikansi (sig) di mana jika nilai sig di bawah 0,05 maka variabel independen berpengaruh terhadap variabel dependen. Uji F-statistik digunakan untuk membuktikan ada pengaruh antara variabel independen terhadap variabel dependen secara simultan.

\section{HASIL DAN PEMBAHASAN}

Kriteria yang digunakan dalam pengambilan sampel penelitian. 
Tabel 1. Kriteria Sampel Penelitian Berdasarkan tabel kriteria sampel data penelitian di atas, berikut ini adalah hasil pengujian statistik sampel data menggunakan bantuan aplikasi olah data SPSS Versi 23.

\begin{tabular}{|c|c|}
\hline & 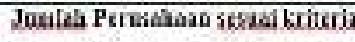 \\
\hline 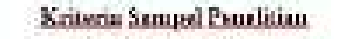 & \\
\hline 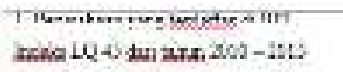 & it \\
\hline 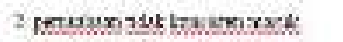 & \\
\hline 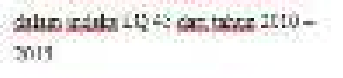 & (7) \\
\hline 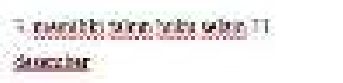 & , \\
\hline 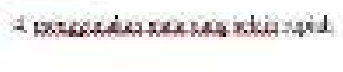 & 0 \\
\hline 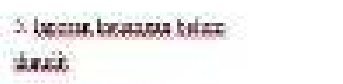 & , \\
\hline 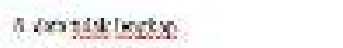 & (2) \\
\hline 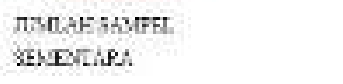 & 16 \\
\hline 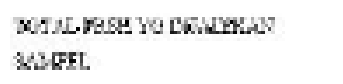 & K \\
\hline 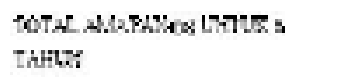 & \% \\
\hline
\end{tabular}

Tabel 2. Uji Statistik Deskripstif Descriptive Statistics

\begin{tabular}{lcccccc}
\hline & \begin{tabular}{c} 
N \\
\cline { 2 - 7 }
\end{tabular} & $\begin{array}{c}\text { Rang } \\
\mathbf{e}\end{array}$ & $\begin{array}{c}\text { Mi } \\
\mathbf{n i}\end{array}$ & $\begin{array}{c}\text { Ma } \\
\mathbf{x i}\end{array}$ & Sum & Mean \\
& $\mathbf{t}$ & $\begin{array}{c}\text { Stati } \\
\text { st }\end{array}$ & $\begin{array}{c}\text { Stati } \\
\text { st }\end{array}$ & $\begin{array}{c}\text { Stati } \\
\text { st }\end{array}$ & Statisti & Statisti \\
& 96 & 1,00 &, 00 & 1,00 & 85,00 &, 8854 \\
Ukuran_K & 96 & 5,10 & 29,35 & 34,44 & 3025,0 & 31,511 \\
Ukuran_Perus ahaan & 96 &, 77 &, 13 &, 91 & 45,97 &, 4789 \\
Tingkat_Lever age & 96 &, 39 &, 02 &, 40 & 11,72 &, 1220 \\
Profitabilitas_Valid & 96 & & & & & \\
N & & & & & & \\
(listwise) & & & & & & \\
\hline
\end{tabular}

Output tampilan SPSS 23 dari hasil olah data statistik deskriptif menunjukkan bahwa jumlah responden $(\mathrm{N})$ sebanyak 96 responden, dengan nilai minimum 0 dan nilai maksimum 1 untuk data ukuran KAP dengan standar deviasi 0,32. Nilai minimum 29,35 dan nilai maksimum 34,44 untuk data ukuran perusahaan dengan standar deviasi 1,43. Nilai minimum 0,13 dan nilai maksimum 0,91 untuk data tingkat leverage dengan standar deviasi 0,23 . Nilai minimum 0,02 dan nilai maksimum 0,40 untuk data profitabilitas perusahaan dengan standar deviasi 0,09 . 
Tabel 3. Hasil Uji Statistik Deskriptif

\begin{tabular}{|c|c|c|c|}
\hline & $\begin{array}{l}\text { Mean } \\
\text { Std. }\end{array}$ & $\begin{array}{c}\begin{array}{c}\text { Std. } \\
\text { Deviati }\end{array} \\
\text { Statisti }\end{array}$ & $\begin{array}{l}\text { Varianc } \\
\text { Statisti }\end{array}$ \\
\hline Ukuran KAP & 03268 & 32019 & 103 \\
\hline Ukuran Perusahaan & 14557 & 1,42633 & 2,034 \\
\hline Tingkat_Leverage & 02376 & 23276 & 054 \\
\hline $\begin{array}{l}\text { Profitabilitas_Perusa } \\
\text { Valid N (listwise) }\end{array}$ & 00988 & 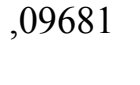 & 009 \\
\hline
\end{tabular}

Tabel 4. Hasil Uji One Sample Kolmogrov-Smirnov TestTabel 4. Hasil Uji One Sample Kolmogrov-Smirnov Test

\begin{tabular}{llr}
\hline & & $\begin{array}{r}\text { Unstandardiz } \\
\mathbf{e}\end{array}$ \\
& & $\begin{array}{r}\text { d Residual } \\
\text { N }\end{array}$ \\
Normal Parameter & & 96 \\
Most Extreme & Mean & .0000000 \\
& Std. Deviation & 15.42297882 \\
& Absolute & .077 \\
Test Statistic & Positive & .077 \\
Asymp. Sig. (2-tailed) & Negative & -.064 \\
& & .077 \\
& & $.196 \mathrm{c}$ \\
\hline
\end{tabular}

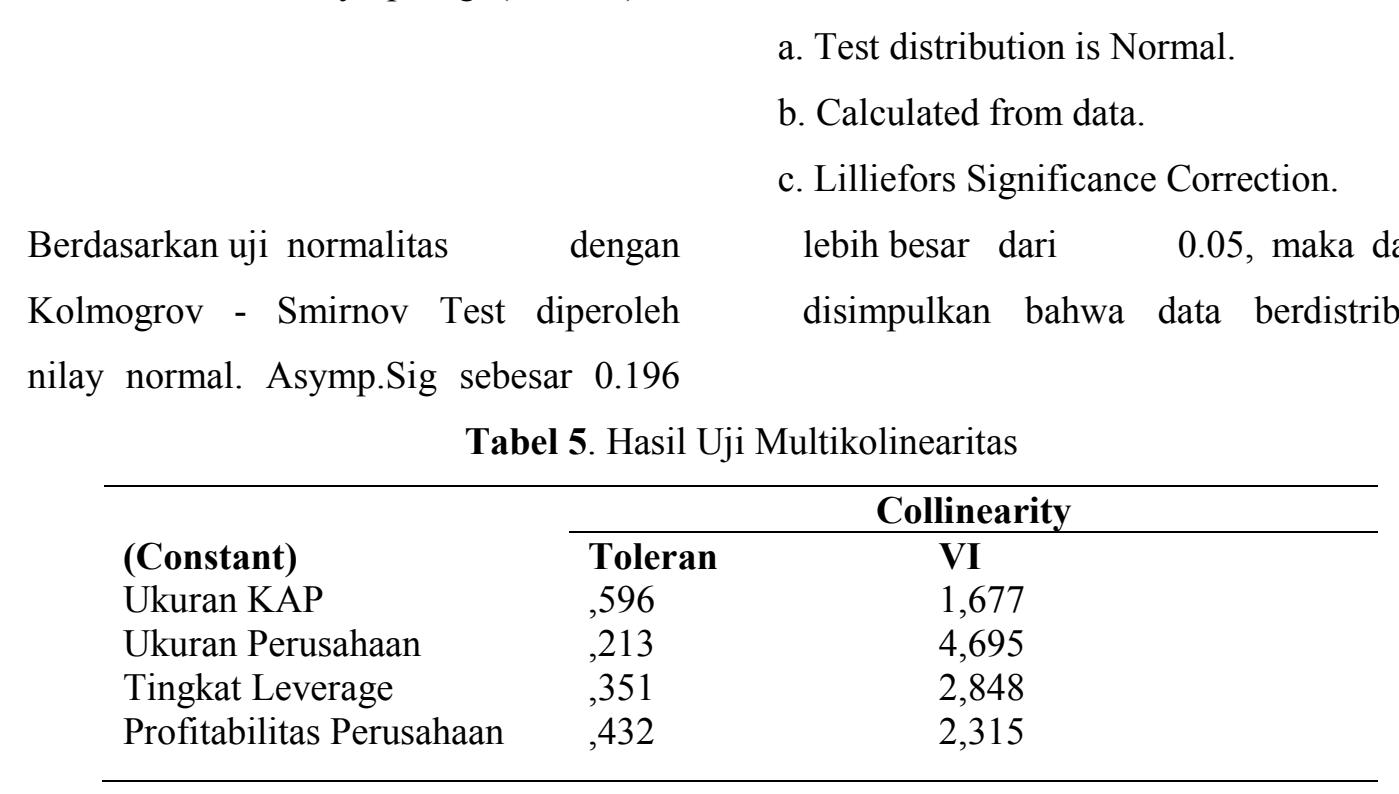

Berdasarkan output olah data, diketahui bahwa nilai toleransi Variabel X1 0.596, X2 0.213, X3 0.351, dan X4 0.423 adalah lebih besar dari 0.10 . Sementara itu nilai VIF variable X1 1.677, X2 4.695, X3
2.848, dan X4 2.315 adalah lebih kecil dari 10.00. Sehingga dapat disimpulkan bahwa tidak terjadi multikolinearitas pada data yang diuji. 
Tabel 6. Hasil Uji Heteroskedastisitas

\begin{tabular}{llllll}
\hline & & & \multicolumn{3}{c}{ Standardi zed } \\
\cline { 3 - 6 } & & & \multicolumn{3}{c}{ Std. } \\
\hline (Constant) & 53,49 & 41,835 & 1,279 &, 204 &, 936 \\
Ukuran KAP & - & 3,797 &,- 010 &,- 080 &, 373 \\
Ukuran & - & 1,426 &,- 192 &,- 896 &, 307 \\
Tingkat & 6,99 & 6,806 &, 171 & 1,028 &, 021 \\
Profitabilitas & - & 14,754 &,- 352 & - & \\
& & & & & \\
\hline
\end{tabular}

Diketahui dari hasil output di atas, nilai signifikansi $\mathrm{X} 1, \mathrm{X} 2, \mathrm{X} 3$, dan $\mathrm{X} 4$ lebih besar dari 0.05. Dapat disimpulkan bahwa data yang diuji memiliki model regresi yang baik karena tidak terjadi heterokedastisitas antar variable yang diuji.

\section{Uji Autokorelasi}

Run test sebagai bagian dari statistik non-parametrik dapat digunakan untuk menguji apakah antar residual terdapat korelasi yang tinggi atau tidak. Jika antar residual tidak terdapat hubungan korelasi maka dikatakan bahwa residual adalah acak atau random. Run test digunakan untuk melihat apakah residual terjadi secara random atau tidak.

Tabel 7. Hasil uji autokorelasi dengan metode run test

\section{Unstandardi}

\begin{tabular}{lr}
\hline Test Value $^{\mathrm{a}}$ & $-1,77694$ \\
Cases $<$ Test Value & 48 \\
Cases $>=$ Test Value & 48 \\
Total Cases & 96 \\
Number of Runs & 44 \\
$\mathrm{z}$ & $-1,026$
\end{tabular}

Asymp. Sig. (2-

tailed)

Hasil run test menunjukkan bahwa nilai Asymp. Sig. (2 tailed) 0,305 > 0,05 yang berarti $\mathrm{HO}$ diterima. demikian data yang dipergunakan cukup random sehingga tidak terdapat masalah autokorelasi pada data yang diuji.

Audit Delay $=0,05+(-4,235) \mathrm{X} 1+1,553$ $\mathrm{X} 2+4,533 \mathrm{X} 3+84,260 \mathrm{X} 4+\mathrm{e}$

Persamaan regresitersebut dapat
dijelaskan sebagai berikut:

a. Koefisien regresi variabel Ukuran KAP memiliki arah negatif dalam pengaruhnya terhadap audit delay.

b. Koefisien regresi variabel Ukuran Perusahaan memiliki arah positif 
dalam pengaruhnya terhadap audit delay.

c. Koefisien regresi variabel Tingkat Leverage memiliki arah positif dalam pengaruhnya terhadap audit delay. d. Koefisien regresi variabel Profitabilititas Perusahaan memiliki arah positif dalam pengaruhnya terhadap audit delay.

Tabel 8. Hasil Uji Regresi Linear Berganda

\begin{tabular}{llllll}
\hline \multicolumn{5}{c}{ Unstandardiz Standardi } \\
\hline \multicolumn{5}{c}{ Std. } \\
\hline (Constant) & 2,893 & 72,051 &, 968 &, 04 &, 968 \\
Ukuran & $-4,235$ & 6,540 &, 519 & - &, 519 \\
Ukuran & 1,553 & 2,456 &, 529 &, 63 &, 529 \\
Tingka & 4,533 & 11,721 &, 700 &, 38 &, 700 \\
Profitabili & 84,260 & 25,410 &, 001 & 3,31 &, 001 \\
\hline
\end{tabular}

Uji Hipotesis menggunakan Uji t Parsial

\section{Hipotesis dalam uji t pertama.}

Berdasarkan output koefisien di atas, diketahui bahwa nilai koefisien regeresi variabel Ukuran KAP (X1) adalah sebesar $-4,235$ bernilai negatif, sehingga dapat dikatakan bahwa Ukuran KAP (X1) berpengaruh negatif terhadap Audit Delay (Y). Selanjutnya, nilai koefisien regresi dari variabel Ukuran KAP (X1) akan diuji signifikansinya [uji t parsial].

1. $\mathrm{H} 0=$ Ukuran KAP (X1) tidak berpengaruh signifikan terhadap Audit Delay (Y).

2. H1 = Ukuran KAP (X1) berpengaruh signifikan terhadap Audit Delay (Y).

berdasarkan hasil analisis regresi diperoleh nilai $\mathrm{t}$ hitung $=-0,648<\mathrm{t}$ tabel $=1,990$ dan nilai Sig. 0,519>0,05. Maka dapat disimpulkan bahwa H0 diterima dan H1 ditolak, yang artinya Ukuran KAP (X1) tidak berpengaruh signifikan terhadap Audit Delay (Y).

\section{Hipotesis dalam uji t kedua.}

Berdasarkan output koefisien di atas, diketahui bahwa nilai koefisien regeresi variabel Ukuran perusahaan (X2) adalah sebesar 1,553 bernilai positif, sehingga dapat dikatakan bahwa Ukuran Perusahaan (X2) berpengaruh positif terhadap Audit Delay (Y). Selanjutnya, nilai koefisien regresi dari variabel Ukuran Perusahaan (X2) akan diuji signifikansinya [uji t parsial].

1. $\mathrm{H} 0=$ Ukuran Perusahaan $(\mathrm{X} 2)$ tidak berpengaruh signifikan terhadap Audit Delay (Y). 
2. $\mathrm{H} 2=$ Ukuran Perusahaan (X2) berpengaruh signifikan terhadap Audit Delay (Y).

Berdasarkan hasil analisis regresi diperoleh nilai t hitung $=0,632<\mathrm{t}$ tabel $=$ 1,990 dan nilai Sig. 0,529>0,05. Maka dapat disimpulkan bahwa H0 diterima dan H2 ditolak, yang artinya Ukuran Perusahaan (X2) tidak berpengaruh signifikan terhadap Audit Delay (Y).

\section{Hipotesis dalam uji t ketiga.}

Berdasarkan output koefisien di atas, diketahui bahwa nilai koefisien regeresi variabel Tingkat Leverage (X3) adalah sebesar 4,553 bernilai positif, sehingga dapat dikatakan bahwa Tingkat Leverage (X3) berpengaruh positif terhadap Audit Delay (Y). Selanjutnya, nilai koefisien regresi dari variabel Tingkat Leverage (X3) akan diuji signifikansinya [uji t parsial].

1. $\mathrm{H} 0=$ Tingkat Leverage (X3) tidak berpengaruh signifikan terhadap Audit Delay (Y).

2. $\mathrm{H} 3=$ Tingkat Leverage $(\mathrm{X} 3)$ berpengaruh signifikan terhadap Audit Delay (Y).

Berdasarkan hasil analisis regresi diperoleh nilai $\mathrm{t}$ hitung $=0,387<\mathrm{t}$ tabel $=$ 1,990 dan nilai Sig. $0,700>0,05$. Maka dapat disimpulkan bahwa $\mathrm{H0}$ diterima dan H3 ditolak, yang artinya Tingkat Leverage
(X3) tidak berpengaruh signifikan terhadap Audit Delay (Y).

\section{Hipotesis dalam uji t keempat.}

Berdasarkan output koefisien di atas, diketahui bahwa nilai koefisien regeresi variabel Profitabilitas Perusahaan (X4) adalah sebesar 84,260 bernilai positif, sehingga dapat dikatakan bahwa Profitabilitas Perusahaan berpengaruh positif terhadap Audit Delay (Y). Selanjutnya, nilai koefisien regresi dari variabel Profitabilitas Perusahaan (X4) akan diuji signifikansinya [uji t parsial].

1. $\mathrm{H} 0=$ Profitabilitas Perusahaan (X4) tidak berpengaruh signifikan terhadap Audit Delay (Y).

2. $\mathrm{H} 4=$ Profitabilitas Perusahaan (X4) berpengaruh signifikan terhadap Audit Delay (Y).

Berdasarkan hasil analisis regresi diperoleh nilai $\mathrm{t}$ hitung $=3,316>\mathrm{t}$ tabel $=$ 1,990 dan nilai Sig. 0,001<0,05. Maka dapat disimpulkan bahwa $\mathrm{H} 0$ ditolak dan H4 diterima, yang artinya Profitabilitas Perusahaan (X4) berpengaruh signifikan terhadap Audit Delay (Y).

\section{Uji Simultan (F)}

Pada prinsipnya, Uji $\mathrm{F}$ bertujuan untuk mengetahui pengaruh dari 2 (dua) variabel independen atau lebih secara simultan (bersama) terhadap variabel 
dependen. Terdapat dua cara yang bisa pengaruh signifikan dalam uji F.

digunakan untuk mengetahui ada tidaknya

Tabel 9. Hasil Uji F Simultan

\begin{tabular}{lllllcc}
\hline Model & $\begin{array}{c}\text { Sum of } \\
\text { Squares }\end{array}$ & Df & $\begin{array}{c}\text { Mean } \\
\text { Squares }\end{array}$ & F & Sig \\
\hline 1 & Regressio & 3982,472 & 4 & 995,618 & 4,009 &, $005 \mathrm{~b}$ \\
& Residual & 22597,486 & 91 & 248,324 & & \\
& Total & 26579,958 & 95 & & & \\
\hline
\end{tabular}

a. Dependent Variable: Audit Delay

b. Predictors: (Constant), Profitabilitas Perusahaan, Ukuran KAP, Tingkat Leverage, Ukuran perusahaan

Hasil olah data menunjukkan bahwa $\mathrm{k}=4$ dan $\mathrm{n}=96$. Selanjutnya nilai ini dimasukkan dalam rumus maka mengahsilkan angka $(4 ; 96-4)=(4 ; 92)$. Maka diketahui bahwa nilai $\mathrm{F}$ hitung = 4,009 $>\mathrm{F}$ tabel $=2,47$ maka variabel independen (bebas) secara simultan berpengaruh terhadap variabel dependen (terikat). Sedangkan nilai signifikansi $0,005<0,05$ maka variabel independen secara bersama-sama berpengaruh signifikan terhadap variabel dependen. Dalam hasil perhitungan tersebut, maka pengambilan keputusan dalam uji $\mathrm{F}$ baik itu membandingkan nilai $\mathrm{F}$ hitung dengan nilai $\mathrm{F}$ tabel, maupun berpedoman pada nilai signifikansi diperoleh hasil yang konsisten. Penelitian dilakukan dengan mengacu pada data sekunder berupa laporan keuangan auditan dalam jangka waktu 6 tahun berturut-turut, dari tahun 2010- 2015. Sesuai dengan beberapa kriteria sampel yang telah ditnetukasn sebelumnya, terdapat 16 perusahaan dengan total 96 sampel laporan keuangan auditan.

Untuk menguji apakah sampel yang diambil memenuhi kriteria dalam pengujian analisis regresi linier berganda, telah dilakukan serangkaian uji statistik menggunakan alat bantu pengolahan data SPSS versi 23. Sesuai hasil penelitian pengolahan data menggunakan uji statistik, diperoleh hasil penelitian sebagai berikut:

1. Hasil uji statistik menunjukkan bahwa Ukuran KAP (X1) tidak berpengaruh terhadap Audit Delay (Y). Hasil ini tidak mendukung teori atribusi yang menyatakan bahwa faktor pengalaman, kemampuan, keterampilan serta motivasi mempengaruhi peningkatan kinerja.

2. Hasil uji statistik menunjukkan bahwa Ukuran Perusahaan (X2) tidak berpengaruh terhadap Audit Delay (Y). Hasil ini tidak 
mendukung teori struktur modal

yang menyatakan cara

memaksimalkan nilai perusahaan yaitu dengan menciptakan struktur modal yang optimal dan memaksimalkan harga sahamnya.

3. Hasil uji statistik menunjukkan bahwa Tingkat Leverage (X3) tidak berpengaruh terhadap Audit Delay (Y). Hasil ini tidak mendukung teori sturuktur modal yang dikembangkan oleh Modigliani dan Marton Miller (teori MM) yang menyimpulkan bahwa bauran pendanaan (financing mix) dapat mempengaruhi nilai perusahaan. Suatu penentuan tingkat leverage keuangan yang optimal atau komposisi pendanaan optimal dengan meminimalkan biaya modal perusahaan adalah setara dengan memaksimalkan nilai pasar perusahaan (Sawir, 2004:43).

4. Hasil uji statistik menunjukkan bahwa Profitabilitas Perusahaan (X4) berpengaruh terhadap Audit Delay (Y). Hasil ini mendukung teori pragmatik yang menyatakan kaitan antara laba yang telah dimaknai dengan perilaku investor atau penerima lainnya.
5. Hasil uji sumultan F menunjukkan diketahui bahwa nilai $\mathrm{F}$ hitung $=4,009>\mathrm{F}$ tabel $=$ 2,47 maka variabel independen (bebas) secara simultan berpengaruh terhadap variabel dependen (terikat). Sedangkan nilai signifikansi $0,005<0,05$ maka variabel independen secara bersama-sama berpengaruh signifikan terhadap variabel dependen. Dalam hasil perhitungan tersebut, maka pengambilan keputusan dalam uji $F$ baik itu membandingkan nilai $F$ hitung dengan nilai $\mathrm{F}$ tabel, maupun berpedoman pada nilai signifikansi diperoleh hasil yang konsisten.

\section{KESIMPULAN}

Berdasarkan hasil uji statistik data sekunder penelitian dan pembahasan yang sudah diuraikan dalam Bab IV, maka diperoleh kesimpulan sebagai berikut:

1. Ukuran KAP (X1) tidak mempengaruhi audit delay $(\mathrm{Y})$.

2. Ukuran Perusahaan (X2) tidak mempengaruhi audit delay (Y).

3. Tingkat Leverage (X3) tidak mempengaruhi audit delay $(\mathrm{Y})$.

4. Profitabilitas Perusahaan (X4) mempengaruhi audit delay $(\mathrm{Y})$. 
5. Secara keseluruhan berdasarkan Uji

Simultan dapat disimpulkan bahwa variabel independen (bebas) secara simultan berpengaruh terhadap variabel dependen (terikat) artinya, Ukuran KAP (X1), Ukuran Perusahaan (X2), Tingkat Leverage (X3), dan Profitabilitas Perusahaan (X4) secara bersama-sama mempengaruhi audit delay.

\section{KETERBATASAN}

Dalam penelitian ini, peneliti memiliki beberapa keterbatasan dalam melakukan penelitian, di antaranya :

1. Ketidaktersediaan data laporan keuangan konsolidasian yang lengkap pada serangkaian tahun yang digunakan dalam penelitian dari perusahaan yang terdaftar dalam indeks LQ45.

2. Keterbatasan waktu penelitian, sehingga penelitian di fokuskan hanya pada perusahaan yang terdaftar di Bursa Efek Indonesia dalam indeks LQ45 karena likuiditas perusahaan dianggap mampu mewakili perusahaanperusahaan yang terdaftar di Bursa Efek Indonesia.

3. Tidak semua variabel bebas faktor yang secara teori mampu mempengaruhi audit delay diuji dalam penelitian ini. Penelitian ini berfokus pada beberapa variabel bebas yang dianggap perlu diuji kembali oleh peneliti berdasarkan inkonsistensi hasil beberapa penelitian sebelumnya saja di atas penulis menyarankan:

\section{SARAN}

1. Dalam penelitian selanjutnya, peneliti diharapkan dapat memperoleh data laporan keuangan secara menyeluruh agar dalam proses pemilihan sampel bersyarat, tidak banyak data yang tereliminasi karena ketidaktersediaan data dalam time series yang akan diuji.

2. Disarankan agar penelitian selanjutnya menggunakan data perusahaan yang lebih luas dan tidak hanya berfokus pada satu kriteria data kelompok perusahaan saja.

3. Diharapkan dalam penelitian selanjutnya, peneliti mempertimbangkan pengujian faktor lain yang secara teori mempengaruhi terjadinya audit delay baik dari segi faktor internal maupun eksternal perusahaan.

\section{DAFTAR PUSTAKA}

Chambers, A. E., And S. H . Penman. 1984. Timeliness of Reporting and the Stock Price Reaction to Earnings Announcements. Journal 
of Accounting Research (Spring 1984).

Danandjadja. 2012. Metodologi Penelitian Sosial. Yogyakarta : Graha Ilmu.

Lourentya, Febrina Novit.2016. FaktorFaktor yang Mempengaruhi Audit Delay (Studi Kasus Pada Perusahaan Manufaktur yang Terdaftar Di Bursa Efek Indonesia Tahun 2013-2015). Skripsi. Universitas Muhammadiyah Surakarta.

Sarwono, Jonathan. 2006. Metode Penelitian Kuantitatif dan Kualitatif. Edisi Pertama. Yogyakarta : Graha Ilmu.
Sawir, Agnes. 2004. Kebijakan Pendanaan dan RestrukturisasiPerusahaan.

Cetakan Pertama. Jakarta : Gramedia.

Tambing, Eko. 2016. Analisis Determinan Audit Delay pada Perusahaan LQ 45 yang Terdaftar Pada BEI Tahun 2011 - 2015. Skripsi. Universitas Hasanuddin Makassar.

Wahyu, Agatya. 2016. Analisis FaktorFaktor yang Mempengaruhi Audit Delay (Studi Empiris Pada Perusahaan-Perusahaan yang Terdaftar Sebagai Anggota LQ45 di BEI Periode 2013-2015). Skripsi. Universitas Gadjah Mada. 